\title{
Delimitation of landscape units treated as estimation fields in the modelling of a landscape system
}

\begin{abstract}
The main objective of this paper is to represent the hierarchical structure of an environment by using two concepts: typology and regionalization. The Płock Region $(1,766.95 \mathrm{sq} . \mathrm{km})$ and transect crossing this area (796.2 sq. $\mathrm{km}$ ) is the research location. It was divided into 710 individual landscape units (319 in the transect border). The existing physicalgeographical regionalization, including macro-, meso- and micro-regions, was elaborated using a deductive (top-down) method, which was supplemented by a more detailed regionalization, obtained by an inductive (bottom-up) method called analysis of borders (Richling 1976). The study area was divided into more detailed sub-regions: first-level regions (87 units), second-level regions (36 units) and third-level regions (9 units). In fact, the landscape structure of third-level regions is similar to microregions. This is proof of the complementary nature of the two approaches - deductive and inductive regionalization, and the hierarchical landscape structure.
\end{abstract}

Keywords

Landscape structure $\bullet$ typology $\bullet$ regionalization

(C) University of Warsaw - Faculty of Geography and Regional Studies

\author{
Andrzej Richling ${ }^{1}$, \\ Ewa Malinowska², \\ Iwona Szumacher ${ }^{3}$ \\ ${ }^{1}$ Department of Geoecology \\ Institute of Physical Geography \\ Faculty of Geography and Regional Studies \\ University of Warsaw \\ Department of Tourism and Recreation \\ Faculty of Health and Social Sciences \\ Pope John Paul II State School of Higher \\ Education in Biała Podlaska \\ e-mail: a.richling@uw.edu.pl \\ 2Department of Geoecology \\ Institute of Physical Geography \\ Faculty of Geography and Regional Studies \\ University of Warsaw \\ e-mail:emal@uw.edu.pl \\ ${ }^{3}$ Department of Geoecology \\ Institute of Physical Geography \\ Faculty of Geography and Regional Studies \\ University of Warsaw \\ e-mail: szumi@uw.edu.pl \\ Received: 7 October 2013 \\ Accepted: 5 December 2013
}

Introduction

Current landscape unit delimitation methods pertaining to landscape ecology originate from complex physical geography, in particular from the concept of partial geocomplexes and geosystems. Their authors, Haase (1964) and Soczawa (1978), assumed the actual and objective nature of geocomplexes among others, as well as the need to identify individual spatial units in detail. The approach has become obsolete due to the progressive development of the theory and methodologies used in landscape ecology, in particular since nowadays landscape is treated as a large-scale hierarchical structure, with a specific set of structures and processes for each scale range. Following this approach, spatial landscape units (geocomplexes, landscapes, etc.) are classified based on (a) the purpose of the study; (b) its scale; (c) the adopted criteria of classifying and combining units. The theory of systems implies, however, that there is no single preferred procedure or universal spatial unit (Richling, Ostaszewska 1993). Therefore, each time the analysed spatial system, its scale, hierarchy, borders and surroundings should be clearly determined (Kay 1993).

The paradigm of geocomplexes and adequacy of separated spatial units for the assumed purpose and scale of research have long been discussed by a number of authors (Kondracki, Richling, 1983, Pietrzak 1995; 1998; 2011; Richling, Solon 1996; 2011; Widacki 1994 et al.), who raised the ambiguity of separating both basic homogenous spatial units and their aggregation into heterogeneous geocomplexes (Fortin et al. 1996; Jiquan et al. 1996; McNab 1996).

The conclusion is that the scalability of results necessitating the extrapolation of data, beginning with the local and ending with the regional scale, is of crucial importance for the accuracy of assessments and projections.

Therefore, the landscape structure may be identified through components and/or processes analysed on various levels and in various structural and functional systems. Such a broad approach allows the hypothetical separation of a number of spatial unit types and their classification on pre-determined, ontologically consistent hierarchical levels or systems.

Each level in the landscape system hierarchy comprises individual units, which at the same time constitute functiona entities, separated by the different natures of their components, land fragmentation and internal processes. These units consist of individual landscape patches providing the most detailed information on the landscape structure, aggregated on a higher hierarchy level, resulting in generalization.

The criteria underlying the separation of the smallest, homogenous landscape units have been the subject of a number of studies. Abiotic components and land use, as well as necessitating field identification, are the key assumption of delimitation accepted by most landscape ecologists. These patches are of importance, since they can provide the starting 
point for the construction of heterogeneous higher-level spatial units, in both the typological and regional hierarchical system.

The presented spatial unit delimitation problems are becoming particularly important in the era of digitalization and related modelling (conceptual, cartographic and mathematical models). The frequency of these methods in scientific research has been increasing, as they give rise to the question of whether the existing landscape unit paradigm, developed in the course of field and office studies, suits the purpose of reflecting the actual status of a landscape, its structure and functioning in the scope corresponding to the functional and hierarchical diversity of space, flow and characteristics.

In other words, are the landscape units structured in a multilevel typological or regional system the optimal base fields on which to construct hierarchical models of the landscape system?

The modelling procedure usually includes three broadly defined sub-systems: (a) abiotic, regarding objects and spatial relations determined based on inanimate components; (b) biological, focused on defined groups of organisms and entire ecosystems; (c) anthropogenic, including landscape components produced or modified by humans (Solon 2002). Therefore, typological units should be excluded in advance, since in culture-based landscapes only abiotic components may regularly re-appear in space, while anthropogenic and biotic elements are related to various forms of anthropopressure (mainly land use), depending on nonnatural factors, and therefore demonstrate spatial individualism. Therefore, regional classification units may be considered the optimum modelling fields while basic, homogenous landscape units determined based on field research should be treated as individual units (despite the possibility of classifying them into types in this research stage, since this classification is useless from the viewpoint of the assumed research objective).

In light of the above, the authors of this study have initiated research aimed at the directed classification of a landscape system to be used in later stages of work to evaluate and project bio-geo-diversity.

Landscape has been treated as an entity existing in space and time, and including a variety of interrelated hierarchical systems.

The authors have developed a method to separate the basic fields used to build a hierarchical landscape model. Individual landscape units determined during field work were the starting point. These units were later rigorously grouped into higher level units of regional classification characterized by a determined, unique composition of components and the resulting individualized structure and functioning

\section{Research area}

The area of research is located to the west of the Płock Urban and Industrial Agglomeration, in a lowland landscape. It is dominated by glacial landscapes related to the latest glacial period including the Wisła River, formed into plains, smaller and bigger knolls and hills. A periglacial landscape occupies the southern portion of the surveyed area.

The research was carried out within a transect of $796.2 \mathrm{sq}$ $\mathrm{km}$ (Figure 1). In practice, though, the surveyed range was limited by the borders of typological and regional units used as basic fields for assessments and analyses, entirely or partially included in the transect.

The plot occupies $1,766.95 \mathrm{sq}$. $\mathrm{km}$. To the east and south it is limited by regional units: the sub-province of Pojezierza Południowobałtyckie and the mesoregion of Równina Kutnowska, while its western and northern borders are determined in accordance with geometric principles.

According to the typology of natural Polish landscapes (Richling 1984, Richling, Ostaszewska 2006), the entire area under research is situated in lowlands, with its northern and north-western portion classified as glacial landscapes originating from the latest glacial period including the Wisła River, formed as plains, higher and lower hills and knolls.

The proportion of fluvioglacial and Aeolic landscapes, formed by water flowing from the melting ice sheet, is also substantial. The water deposited sand of various grain sizes, in later stages formed by wind into dunes, often entering adjacent areas.

In the southern part of the plot there are two kinds of landscape: 1) hydrogenous landscapes including valley bottoms and depressions, and 2) periglacial landscapes, formed during older glacial periods, dominated by plains and undulated plains. The entire area is frequented by isles of hills and knolls, mainly of Aeolic origin. The structure of the surveyed landscape is presented in Figure 2.

Based on the physico-geographical regionalization of Poland (Kondracki2000), a similar classification of the Płock Province(Richling Czajkowski 1988) and regional classification of the area affected by the Płock Urban and Industrial Agglomeration (Richling, Malinowska, Lechnio 2005), the surveyed area covers a variety of physicogeographical units. Its northern and middle section belongs to the Pojezierza Południowobałtyckie sub-province (315), while the southern part belongs to the Niziny Środkowopolskie subprovince (318) of the Niż Środkowoeuropejski province (31). The northern and middle part of the transect is located within the Pojezierze Chełmińsko-Dobrzyńskie macroregion (315.1), the Pojezierze Dobrzyńskie mesoregion (315.14) and the Pojezierze Dobrzyńskie Właściwe microregion (315.142).

The southern part of the transect lies across the Pradolina Toruńsko-Eberswaldzka macroregion (315.3), the Kotlina Płocka mesoregion (315.36) and three microregions: Poziom Duninowski (315.362), Poziom Brwilna-Radziwia (315.363) and Pojezierze Łąckie (315.364).

Just a small portion in the south-west is included in the Nizina Środkowomazowiecka macroregion (318.7), the Równina Kutnowska mesoregion (318.71) and the Równina Gąbińska microregion (318.713).

Data and analysis tools

The vector and raster data were the source of information regarding the surveyed area including:

- A detailed geological map of Poland 1:50 000, the sheet including Tłuchowo, Dobrzyń, Płock and Gąbin,

- A geological and economic map of Poland 1:50 000, the sheet including Tłuchowo, Dobrzyń, Płock and Gąbin,

- A hydrographic map of Poland 1:50 000, the sheet including Płock and Gąbin,

- Soil and agricultural maps 1:5 000 and 1:25 000,

- A soil classification map 1:5000,

- A soil and habitat map 1:10 000 of the Płock, Gostynin and Łąck forest inspectorate,

- Forest valuation reports of the Płock, Gostynin and Łack forest inspectorate,

- A potential vegetation map of Poland 1:300 000,

- A topographic map of 1992 http://geoportal.gov.pl

- Satellite photos Landsat ETM, TM 5 and 7 ,

- The Central Database of National Institute of Geology http:// baza.pgi.gov.pl

- Information collected in the course of field mapping under the project 6PO4 G 09121 - Model of lowland landscape functioning and its use in indication of environmental evolution, - Own research carried out by the authors.

The collected data were processed with ArcGis v.10, eCognition v.8 and Statistica v.10 software and adjusted (generalized) to the scale of 1:50 000 . 


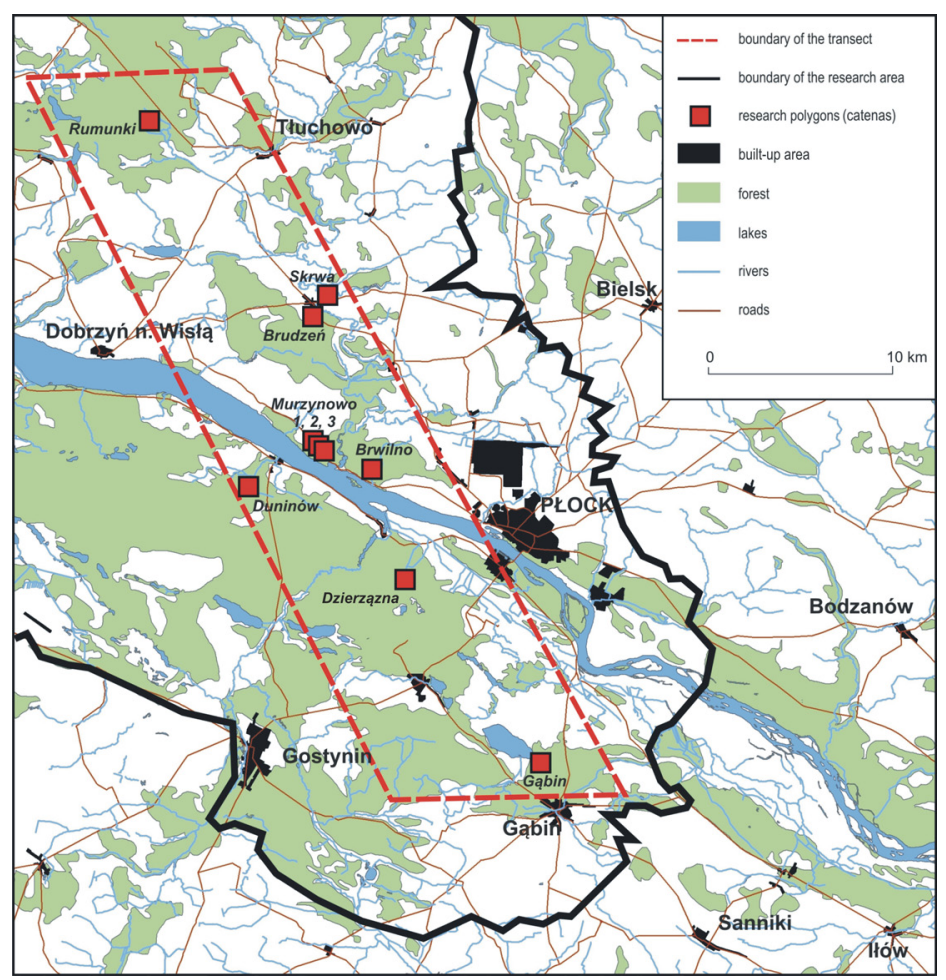

Figure 1. The research transect (Source: own study)

\section{Spatial unit delimitation method}

As previously mentioned, spatial units which, according to the authors, are useful in building a hierarchical model of the landscape system should be determined on the regional level.

Therefore, the regionalization procedure was carried out based on the following assumptions:

1. Differences in the structure of individual units are the criterion underlying classification into regions;

2. Internal structure of the determined regions includes minimum differences, internal consistency and cohesiveness with maximum differences between regions;

3. A region as a whole operates in a clearly determined manner, although certain internal heterogeneity occurs.

An induction based approach, involving grouping of units into higher-order ones beginning from the basic level was assumed as the most appropriate of the regionalization methods.

This approach, relatively rarely applied, allows the correctness of the parameter aggregation procedure to be controlled for a given unit based on an assumed algorithm, as well as enabling the building of higher-level units of regional classification whose ceiling is not substantially limited by the method but only by the model and its possible applications. Furthermore, when units are combined, their natural structure and spatial composition (landscape mosaic) is preserved within the higher-order units.

The unit grouping procedure was based on individual landscape patches with detailed parameters determined. In the course of combining, their natural structure and spatial composition (landscape mosaic) was preserved within the higherorder units.

Therefore, the Papadimitriou principle (2002) that structural dynamics should be considered in relation to spatial units and their borders (based on the model of dynamics of functioning in relation to internal diversity within landscape mosaic patches, Richling, Lechnio 2012), can be applied.

The lowest (basic) level of the hierarchical system of natural units referred to above consists of individual landscape units which, as mentioned before, constitute the lowest (basic) level of the hierarchical system of natural units with the most detailed parameters.

In this case, they were separated using the method of overlapping the borders of the leading environmental components decisive for the landscape structure and functioning - the method of border analysis (Richling 1976; 1992) ${ }^{1}$, simultaneously determining matter and energy flow processes in geosystems

${ }^{1}$ Correct use of the key factor method to delimit landscape units in areas subject to anthropopressure is sometimes undermined (Richling 1992). Some authors indicate that in such cases, the principle of coupled component analysis should be applied since anthropogenic activities that change in space and time are the governing factor determining the functioning of a landscape. Therefore, it is not always key components that correspond to natural systems of other subordinate components. Especially significant distortions may be expected in lithology - land lie - water - vegetation relations.

The surveyed area is located in the reach of diverse, locally high anthropopressure, related mostly to the supply of air pollution from the Płock Urban and Industria Agglomeration (Lechnio, Malinowska 2005) and agricultural use of the land (Lechnio 2005). However, as indicated by local field research (Malinowska, 2005), these do not result in a substantial distortion of relations between the landscape components, which preserve their paranatural character (Malinowska 2005, Lechnio, Richling 2005). The above conclusion is supported among others by a correlative analysis of landscape characteristics.

The produced values of Pearson linear correlation coefficients indicate significant relationships between key and subordinate landscape components. Surface forms play a key role in this respect, while land lie is much less important due to poor morphometric diversity. The results of the correlation analysis indicate relatively little morphometric diversity. At the same time, they prove the absence of a close relation between land use and landscape structure. 


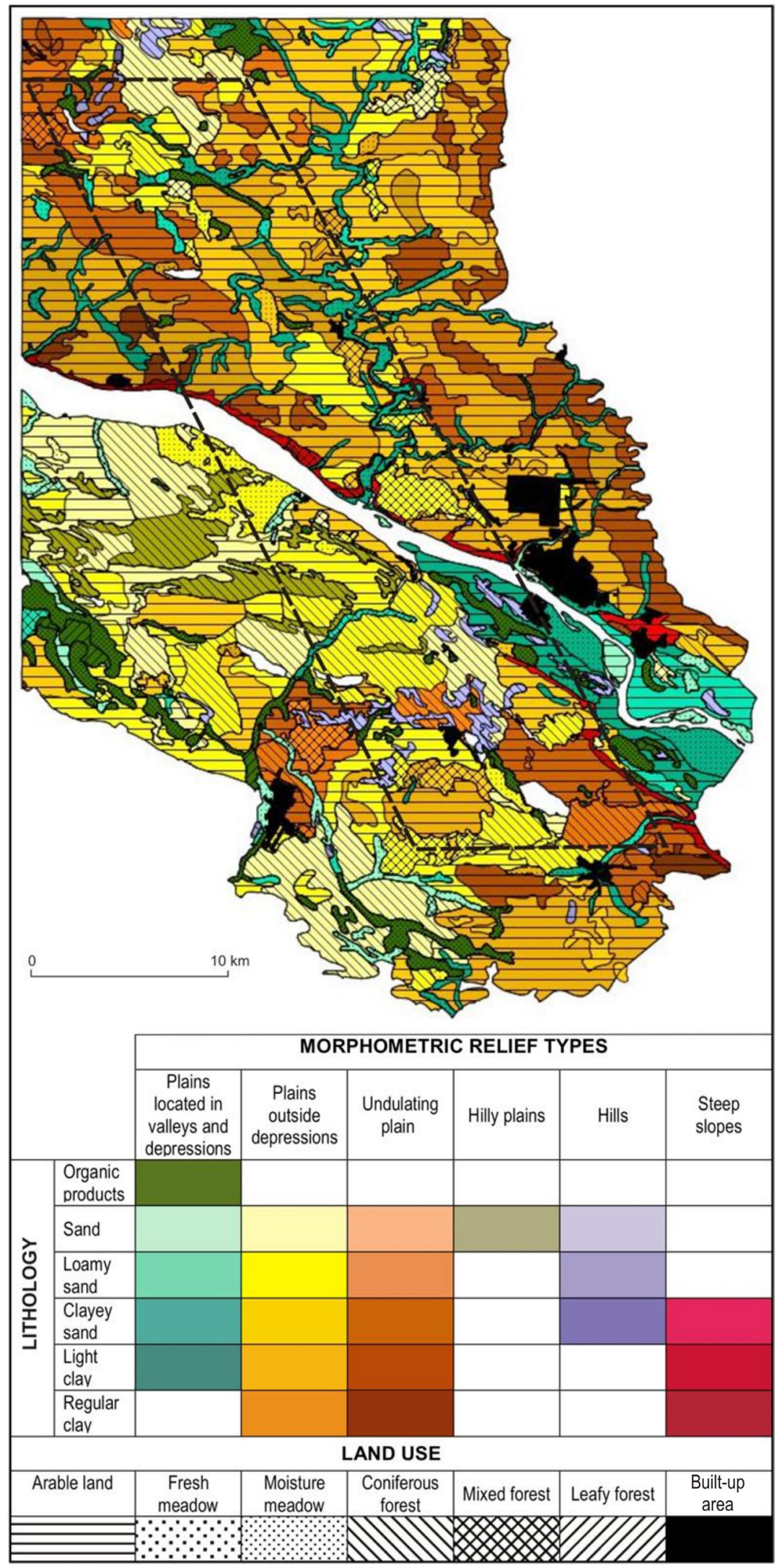

Figure 2. Landscape structure in the surveyed area (Source: own study) 
and the resulting changes within geocomplexes, which consequently determine the corresponding bio- and geodiversity. They may be treated as individual regional units, or as typological classes, since component characteristic systems underlying their delimitation re-occur in space.

When delimiting individual landscape units, the following factors were included:

- surface forms, classified into loose sand, loamy sand, clayey sand, light clay, regular clay and organic products; - morphometric forms (as classified by Richling 1992), classified into plains located in valleys and depressions, plains outside depressions, undulated plains, hilly plains, isolated high and low knolls, high and low hills, as well as steep and gentle slopes;

- land cover related to a defined form of use, classified into arable land, fixed and varying moisture meadows, fresh grassland, coniferous, broadleaf and mixed forests, as well as wasteland ${ }^{2}$

The above factors, considered jointly, determine the type and intensity of substance migration within a landscape (absorption, transport and accumulation), the natural potential of habitats and their utilization barriers resulting from anthropopressure. others:

Surface forms have been assumed to determine, among

- supply and type of chemicals introduced to the matter flow as a result of mineral erosion;

- physical and chemical characteristics of soil including its natural fertility and chemical content;

- resistance to water and wind erosion giving rise to a risk of reduced soil fertility;

- intensity of rainwater infiltration determining the flow (leaching) of chemical and organic substances deeper into the profile:

- water capacity of topsoil and subsoil (the entire aeration zone), determining water and mineral supply available for vegetation;

- chemistry of groundwater (through modification of the composition of infiltrating rainwater);

- accumulation capacity of sorption complex (clay) regarding chemicals introduced into the matter flow as a result of natural (erosion) and anthropogenic (pollution, fertilization etc.) processes, i.e. temporary or permanent limiting of their availability for vegetation and leaching to the groundwater level;

- radiation balance of the ground, determining the thermal conditions of soil and diffusion of pollutants transported in the friction zone, e.g. as a result of convection.

\section{Morphometric terrain forms determine among others:}

- supply of sunlight determining thermal conditions of soil through exposure and, as a result, affecting the biomass production, content of organic substance in the soil and thus its fertility;

- inflow and outflow of clastic matter depending on land lie;

- increased denudation determining the thickness of saprolite cover and exposure of new surfaces to erosion;

- intensity of water erosion, resulting in a risk of reduced soil fertility;

- intensity of surface and mid-surface flow resulting in

2Delimitation did not include the developed areas (human settlements) occupying a total space of $30.72 \mathrm{sq} . \mathrm{km}$ in the surveyed area (7.7 sq. $\mathrm{km}$ in the transect) relocation of chemical and organic components from autonomous to subordinate areas (according to Perelman's elementary landscape concept, 1979);

- air transport of pollutants including occurrence of zones with unfriendly sanitary conditions (still air pools, poor draft zones etc.);

- depth and shape of groundwater table and the speed of groundwater flow in the saprolite cover.

Land cover related to a defined form of use determines among others:

- absorption of pollutants transported by air as a result of varying roughness;

- biomass production as the key source of humus in forests and grasslands;

- oversupply of chemicals to the matter flow as a result of agricultural measures, which may result in changes to the chemical composition of the landscape as determined by natural processes;

- topoclimate, through determining of albedo, evapotranspiration and air flow;

- water flow through the effects of evaporation on surface flow with permanent or seasonal lack of vegetation, intense erosion and stabilization of the ground cover layer.

The performed procedures resulted in the determination of 710 individual landscape units in the surveyed area (319 within the transect) (Figure 2). In the course of the work, these units were aggregated into higher-order ones (first, second and third-level regions) treated as basic fields for the evaluation of landscape structure and functioning.

The first-level regions were delimited by the border analysis method (Richling 2002). The procedure involved the separation of borders between input units, i.e. basic individual landscape patches. Regionalization included composing small environmental units of homogenous structure (at the assumed detail level) into regions. The weight of borders was decisive for determining regional ones, depending on the number of characteristics differentiating adjacent units. It was assumed that changing any single feature (land lie, lithology or the form of use) does not differentiate the units, so such adjacent units were combined into larger ones. When, on the other hand, separated patches differed in two or more ways, the border was preserved. The process of combining adjacent units was reiterated until an area was separated, closed with a border, along which a minimum of any two features changed compared to adjacent areas. "Alien" units may occur within so determined regions, separated by two or more characteristics. Their presence is a crucial factor determining the unique character of each region.

In the next stage of regionalization (second-level regions), the procedure of combining units into higher-order ones followed the key characteristic principle. It was assumed that if within adjacent first-level regions at least two identical key characteristics occur (identical with delimitation criteria for individual types of landscape patches), the regions are combined. Also in this case, in the second-level regions alien regions (first-level) occurred, the presence of which is a crucial element of a region's specific features.

The last stage of regionalization, following the border analysis principles, involved determining third-level regions through the composition of second-level ones, but only when their key characteristics were not contrasting or contradictory.

Region borders were similar to those of microregions determined by the deduction method (Richling, Czajkowski 1988). Therefore, it may be stated that third-level regions determined with 

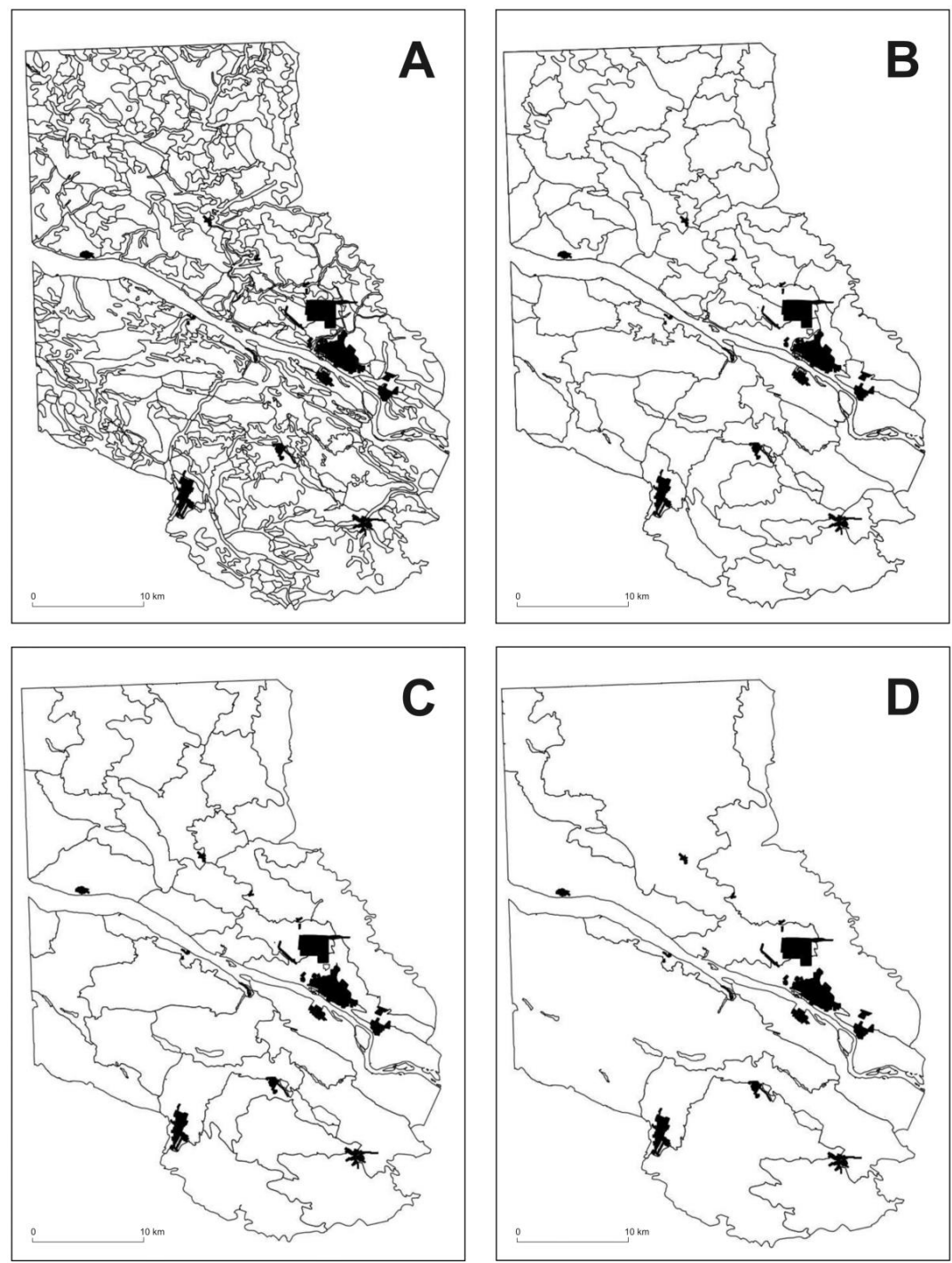

Figure 3. Regional classification of the surveyed area. A-individual landscape units (710), B - first-level regions (87), C - secondlevel regions (36), D - third-level regions (9) Source: own study

the lower-level unit combining method correspond in structural terms to microregions determined in the physico-geographical classification of the territory of Poland arising from the division of higher-level units. This regularity supports the conclusion of the complementary character of deduction and induction-based methods of regionalization formulated by Richling (1992).

The above procedure resulted in the delimitation of 87 firstlevel regions, 36 second-level regions and 9 third-level regions (Figure 3).

The analysis of internal diversity in landscape structure and functioning within the separated regional units indicates that individual units and first-level regions are the most homogenous with a specified composition of individual units, and a relatively small share of alien units (usually river valleys dividing uplands or isolated hills, mainly dunes).

Therefore, biological processes (habitat and use) and physico-chemical conditions determining direction and pace of matter flow and the analysis of the internal landscape structure within their borders can be parameterized. Higher-order regions resulting from the grouping of lower-order regions show more significant internal diversity.
The applied method of complementary units allowed the separation of a complementary and hierarchical system of units, both in terms of functional and structural (horizontal) hierarchy. In terms of function, the classification results in three hierarchical, adjacent levels, allowing the performance of key analyses and simulations of relationships within a landscape system.

The described approach corresponds to theoretical assumptions that describe the functioning of hierarchical landscape systems, including the nature and functioning of borders (Kulczyk 2012).

\section{Conclusion}

Landscape system modelling requires the sorting of data that describe such a system. The process should ensure the reflection of actual interaction between ecosystem processes and the related natural systems, including changes introduced by humans. The appropriate delimitation of spatial units reflecting the hierarchical order of the landscape system is therefore of crucial importance and often determines the success of a model construction. Additionally, transition from topical level units, usually treated as fields for the integration of data derived from 
direct field work to a heterogeneous surface on the regional level (usually described and parameterized based on remote detection methods) is the key problem, and is still unsolved.

The heterogeneous spatial distribution of landscape components, often depending on non-natural factors, makes regional classification units of varying diversity the optimal basic modelling fields. The induction based approach has proven to be the most appropriate of the existing regionalization methods, as it involves grouping units into higher-order regions starting from basic ones. The alternative regionalization manner, involving the division of large regions into lower-order units based on key factors seemed not to be applicable in this case since it was continued up to the mesoregion level (only locally to the microregion level). These units, due to their scale, aggregation level of differentiating characteristics and heterogeneity, disallow a detailed reflection of the landscape status, structure and functioning in the scope corresponding to the functional and hierarchical diversity of space, or a detailed evaluation and analysis of elementary landscape structure in the surveyed area. Continuation of the regionalization method (according to the assumptions of Kondracki 2000) necessitates a change in the classification criteria (adequate to the increasing landscape diversity) involving descending to the lowest levels, limiting the comparability of the weighting of criteria used to determine regions and the related parameterization of landscape characteristics.

\section{Acknowledgement}

The paper was prepared under the research project of the Ministry of Science and Higher Education - project number $\mathrm{N}$ N305 322135 "Hierarchical model of the natural system and its use for geo- and biodiversity assessment and forecasting."

\section{References}

Fortin, MJ, Drapeau, P \& Jacquez, GM 1996, 'Quantification of the spatial co-occurrences of ecological boundaries', Oikos, vol. 77, no. 1, pp. 51-60.

Haase, G 1964, Landschaftsokologische Detailuntersuchung und Naturraumliche Gliederung, Pet. Geogr. Mitt., 1-2.

Jiquan, C, Franklin, JF \& Lowe, JS 1996, 'Comparison of abiotic and structurally defined patch patterns in hypotheticalforest landscape', Conservation Biology, vol. 10, no. 3, pp. 854862.

Kay, JJ 1993, 'On the Nature of Ecological Integrity: Some Closing Comments' in Ecological Integrity and the Management of Ecosystems eds S Woodley, JJ Kay \& G Francis, St. Lucie Press, Delray, Florida, pp. 210-212.

Kondracki, J 2000, Geografia regionalna Polski [Regional Geography of Poland], PWN, Warszawa (In Polish).

Kondracki, J \& Richling, A 1983, 'Próba uporządkowania terminologii w zakresie geografii fizycznej kompleksowej', Przegl. Geogr., vol. 55, no. 1.

Kulczyk, S 2012, 'Charakterystyka granic krajobrazowych okolic Płocka' [The character of landscape boundaries within Płock area] in Model Funkcjonowania Systemu Krajobrazowego, eds A Richling \& J Lechio, WGSR UW, Warszawa, pp. 7794.

Lechnio, J 2005, 'Użytkowanie terenu w strefie oddziaływania PZM-P w okresie 1987-1999' in Z Problematyki Funkcjonowania Krajobrazów Nizinnych, eds A Richling \& J Lechnio, WGSR UW, Warszawa, pp. 89-94.

Lechnio, J \& Malinowska, E 2005, 'Wykorzystanie metod biomonitoringu do oceny dostawy atmosferycznej wybranych metali w rejonie PZM-P' in Z Problematyki Funkcjonowania Krajobrazów Nizinnych, eds A Richling \& J Lechnio, WGSR UW, Warszawa, pp. 127-144.

Lechnio, J \& Richling, A 2005, 'Model funkcjonowania krajobrazu - ocena dynamiki z zastosowania analizy potencjału' in Z Problematyki Funkcjonowania Krajobrazów Nizinnych, eds A Richling \& J Lechnio, WGSR UW, Warszawa, pp. 255271.

Malinowska, E 2005, 'Zastosowanie parametrów pokrywy glebowej do opisu procesów funkcjonowania krajobrazu' in Z Problematyki Funkcjonowania Krajobrazów Nizinnych, eds A Richling \& J Lechnio, WGSR UW, Warszawa, pp. 147-188.

McNab, WH 1996, 'Classification of local- and landscape-scale ecological types in the southern Appalachian Mountains', Environmental Monitoring and Assessment, vol. 39, no. 1-3, pp. 215-229.
Papadimitriou, F 2002, 'Modelling indicators and indices of landscape complexity: an approach using GIS', Ecological Indicators, vol. 2, pp. 17-25.

Perelman, AJ 1971, Geochemia krajobrazu [Geochemistry of Landscape], PWN, Warszawa (In Polish).

Pietrzak, M 1995, 'Średnioskalowa mapa krajobrazowa eksperyment kartograficzny' in Studia krajobrazowe jako podstawa racjonalnej gospodarki przestrzennej, ed M Ruszczycka-Mizera, Wyd. IG Uniw. Wrocł., pp. 61-69.

Pietrzak, M 1998, Syntezy krajobrazowe - założenia, problemy, zastosowania [Landscape Syntheses - Assumption, Problems, Applications], Bogucki Wydawnictwo Naukowe, Poznań.

Pietrzak, M 2011, Podstawy i zastosowania ekologii krajobrazu [Foundations and applications of landscape ecology], Państwowa Wyższa Szkoła Zawodowa im. J.A. Komeńskiego w Lesznie.

Richling, A 1976, 'Analiza i struktura środowiska geograficznego i nowa metoda regionalizacji fizycznogeograficznej (na przykładzie województwa białostockiego)', Rozprawy UW, vol. 104, Wydawnictwo Naukowe UW, Warszawa.

Richling, A 1984, 'Typology of natural landscape in Poland on the scale of 1:5000000', Miscellanea Geographica, pp. 27-32.

Richling, A 1992, Kompleksowa Geografia Fizyczna [Complex Physical Geograph], Wydawnictwo Naukowe PWN, Warszawa (In Polish)

Richling, A \& Czajkowski 1988, 'Regionalizacja fizycznogeograficzna województwa płockiego', Notatki Płockie, no. 1.

Richling, A, Malinowska, E \& Lechnio, J 2005, 'Typologia i regionalizacja krajobrazu terenów w strefie oddziaływania Płockiego Zespołu Miejsko-Przymysłowego' in Z Problematyki Funkcjonowania Krajobrazów Nizinnych, eds A Richling \& J Lechnio, WGSR UW, Warszawa, pp. 29-54.

Richling, A \& Ostaszewska, K 1993, 'Czy istnieje uniwersalna przyrodnicza jednostka przestrzenna?' Przegl. Geogr., vol. 54 , no. $1-2$, s. 59-73.

Richling, A \& Ostaszewska, K 2006, Geografia fizyczna Polski [Physical Geography of Poland], PWN, Warszawa, pp. 296-297.

Richling, A \& Solon J 1996, Ekologia krajobrazu [Landscape ecology], Państwowe Wydawnictwo PWN, Warszawa.

Richling, A \& Solon J 2011, Ekologia krajobrazu [Landscape ecology], Państwowe Wydawnictwo PWN, Warszawa.

Soczawa, WB 1978, Wwiedienie w uczenie o geosistternach. Nauka, Nowosybirsk. 
MISCELLANEA GEOGRAPHICA - REGIONAL STUDIES ON DEVELOPMENT

Vol. $17 \cdot$ No. $4 \cdot 2013 \cdot$ pp. 13-20 • ISSN: 2084-6118 • DOI: 10.2478/v10288-012-0048-8

Solon, J 2002, 'Ocena różnorodności krajobrazu na podstawie analizy struktury przestrzennej roślinności' [The Assessment of Diversity of Landscape on the Basis of Analysis of Spatial Structure of Vegetation], Prace Geograficzne, vol. 185, pp. 1-233.
Widacki, W 1994, 'The end of the geocomplex paradigm in physical geography?' in Landscape research and its applications in environmental management eds A Richling, E Malinowska \& J Lechnio, Uniwersytet Warszawski, Warszawa, pp. 109-113. 